\title{
Poor Feeding Pattern as a Factor Militating Against Students' Achievement in Chemistry; A Mechanism for Sustainable Development
}

\author{
Ibrahim Muhammad Shamsuddin ${ }^{1, *}$, Abdullahi Babale ${ }^{2}$, Adamu Tairu Arome ${ }^{3}$, \\ Mustapha Yusuf $\mathrm{Hamza}^{4}$ \\ ${ }^{1}$ Science Department, Maude International Schools, Zaria, Nigeria \\ ${ }^{2}$ Department of Chemistry, Federal College of Education, Zaria, Nigeria \\ ${ }^{3}$ Biology Department, Federal College of Education, Zaria, Nigeria \\ ${ }^{4}$ Department of Pure and Industrial Chemistry, Faculty of Natural and Applied Science Umaru Musa Yar'adua University, Katsina, Nigeria
}

Email address:

msibzuntu@gmail.com (I. M. Shamsuddin)

${ }^{*}$ Corresponding author

To cite this article:

Ibrahim Muhammad Shamsuddin, Abdullahi Babale, Adamu Tairu Arome, Mustapha Yusuf Hamza. Poor Feeding Pattern as a Factor Militating Against Students' Achievement in Chemistry; A Mechanism for Sustainable Development. Teacher Education and Curriculum Studies. Vol. 2, No. 3, 2017, pp. 20-28. doi: 10.11648/j.tecs.20170203.11

Received: June 11, 2017; Accepted: June 30, 2017; Published: July 24, 2017

\begin{abstract}
This research work examined poor feeding pattern as a factor militating against students' academic achievement in chemistry which is a mechanism to sustainable development. Its main objective is to examine the Effects of feeding pattern on Academic Achievement of Students and to find out whether poor feeding is gender sensitive or not. In this study, a survey research design was used with an instrument titled Feeding Pattern as a Factor Militating against Students' Achievement in Chemistry Questionnaire (FPMSACQ) and also their examination results for first term 2014/2015 academic session as data collection instrument with three hundred and six (306) respondents from six selected secondary schools from Sabon Gari local Government Area of Kaduna state chosen as sample using Krejcie and Morgan table of determining sample size. The analytical tools used was statistical package for social sciences (SPSS, Version 20). The result obtained shows that food insecurity has no significant effect on student's academic achievements in the study area this is as a result of the fact that the students were found to have good feeding pattern, since the $\mathrm{P}$ value is higher than the alpha level of significance $\leq 0.05$. Further investigation and analysis was done which shows that food security has significant effect on the student's academic achievement since the alpha level of significance was found to be $\mathrm{P} \leq 0.05$. It is recommended that the government should inculcate standard educational programs for orphans and also NGO's should aid the government.
\end{abstract}

Keywords: Feeding Pattern, Chemistry Students, Academic Achievement, Sustainable Development

\section{Introduction}

Food is one of the most basic needs necessary for human survival and is achieved through qualitative feeding practices. The feeding practices and access to appropriate quality and quantity of foods are vital components of optimal nutrition for young children [1]. According to the United States' Department of Agriculture [2] food security is defined as having dependable access to enough food for active and healthy living. Conversely, poor feeding pattern or lack of consistence access to adequate food means that the food intake of one or more household members was reduced and their eating pattern were disrupted at times during the year because the household lack money and other resources for food. The USDA classifies households by the level of feeding pattern they have experienced i.e. either poor feeding pattern or good feeding pattern. The poor feeding pattern status of household with children is further classified by whether it affects only adult or children, and by the level of poor feeding among children.

Poor feeding pattern is generally defined as chronic condition which is a consequence of over or under- 
consumption of any or several essential of micronutrients relative to the individual psychological and pathological requirements [3]. Children who do not consume adequate amounts of key nutrients such as calcium, potassium and vitamin $\mathrm{C}$ may be unable to work to their full potential at school [4]. [5] Concur that poor feeding in childhood hinder mental development solely by producing permanent structural damage to the brain. A child's brain during the first three years of life is rapidly developing through generation of neurons synapthogenesis, axonal and dendric growth and synapthic pruning of which build upon each other. Any interruption in this process such trauma, stress, under nutrition or lack of nutrient can have long term effects on the brain structure and on the child's social development, emotional development and academic performance. Thus, research has established that poor nutrition in early life can limit long term intellectual development [6]. Implicit to the above children should not be exposed to malnutrition even at an early age for it has to do with academic performance and socio-religious development.

Academic achievement points to the extent to which individuals have gained from a particular curriculum, subject or task based on relatively standardized experiences such as a class test [7]. Effective learning and sound academic achievement are said to constitute an integral part of the goal of schooling [8]. Even the larger society is aware of the long term effect of high or low academic achievement since graduates from educational institutions are expected to shape the destiny of society [9]. Unfortunately, academic achievement is on the downward trend and this has remained on the sacrosanct (grave) concern to many educationist [10]. Education is one of the most important factor in Nigeria quest to become one of the largest economies by the year 2020. However, with the recent state of education in Nigeria, measures need to be taken to over head the system in order for it to serve as a reliable and efficient vehicle for the attainment of vision [11].

Chemistry is one of the science subjects students are to offer at the senior secondary school level, which is identified as one of the important science subjects. Thus, chemistry is a branch of physical science that studies the composition, structure, properties and change of matter. Chemistry deals with such topics as the properties of individual atom, how atoms form chemical bonds to create chemical compounds, the interaction of substances through intermolecular forces that gives matter its general properties, and the interaction of substances. Chemistry is sometimes called central science because it breaches other natural sciences such as physics, geology and geography. Scholars disagree about the entomology of the word chemistry. The history of chemistry can be traced to alchemy, which had been practiced for several millennia in various part of the world.

Bruntland Commision [12] defines sustainable development as the "ability to make development sustainable to ensure that it meets the needs of the present without compromising the ability of the future generations to meet their own needs" the use of this definition has led many to see sustainable development as having a major focus on intergenerational equity. One of the mechanisms for sustainable development is qualitative education which has to do with good academic performance and also good academic performance has a strong link with good feeding pattern.

The education funding Agency (EFA) global monitoring report [13] states that more than quarter of students or children below fifteen years of age in sub-Saharan Africa are underweight due to poor feeding, making them more vulnerable to disease and less able to concentrate in school. Studies on effects of Poor feeding pattern shows an association between Poor feeding pattern and lower cognitive performance and depression [14, 15, 16, 17]. Poor feeding research helps characterized the impact of malnutrition on the quality of life. A study in Lagos and Ibadan shows that Poor feeding pattern is over $70 \%$ [18]. Poor feeding pattern not only affects physical growth and health of children but also their mental and intellectual development, school attendance and academic achievement [18]. Therefore, addressing poor feeding requires knowing the groups and communities affected which is the purpose of this study, to determine poor feeding pattern as a factor militating against students' academic achievement in chemistry which is a mechanism to sustainable development.

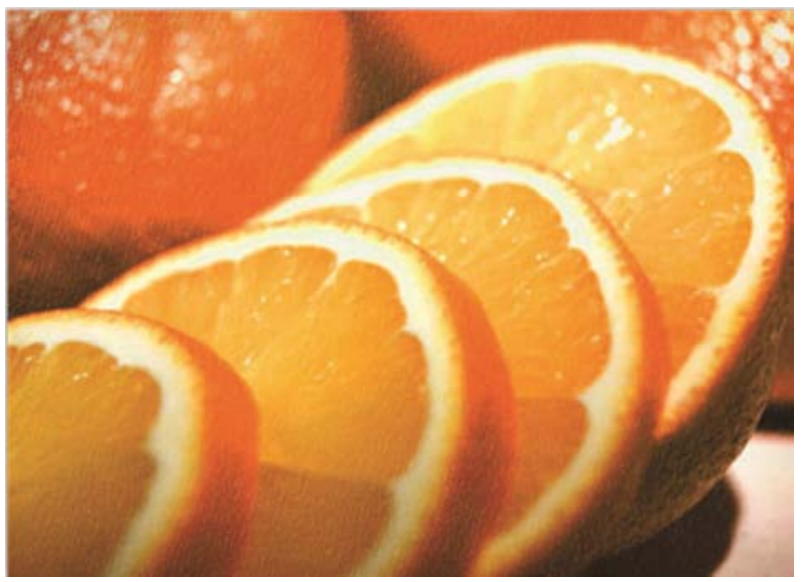

Figure 1. Slice of Oranges [46].

Youth face a number of food related concerns, such as poor nutrition, obesity, and hunger. In 2010, more than onethird of U.S. children and adolescents were overweight or obesity [45], while nearly 20 percent of Minnesota's $9^{\text {th }}$ and $12^{\text {th }}$ grade students were obese [46]. In addition to obesity, children also encounter food insecurity, or limited access to food due to an absence of money or resources. Ten percent of U.S. households with children faced food insecurity in 2012 [47]. In Minnesota, 10 percent of households are classified as food insecure, while it is estimated that 1 in 6 Minnesota children are at risk of hunger [48].

Recent studies have demonstrated that nutrition affects students' thinking skills, behavior, and health, all factors that impact academic performance. Research suggests that diets high in trans and saturated fats can negatively impact learning and memory, nutritional deficiencies early in life can 
affect the cognitive development of school-aged children, and access to nutrition improves students' cognition, concentration, and energy levels [65].

For example, one study found that $5^{\text {th }}$ grade students with less nutritious diets performed worse on a standardized literary assessment [49]. Another study discovered that $5^{\text {th }}$ grade students who ate more fast food fared worse on math and reading scores [50]. Similarly, a study that analyzed a healthy eating campaign that banned junk food from schools and introduced healthier, freshly prepared school meals found that participating students scored higher on English and science tests than students who did not take part in the campaign [51].

Nutrition also indirectly impacts school performance. Poor nutrition can leave students' susceptible to illness or lead to headaches and stomachaches, resulting in school absences [52]. Access to nutrition that incorporates protein, carbohydrates, and glucose has been shown to improve students' cognition, concentration, and energy levels [53, 54].

In contrast, nutritional deficiencies (particularly zinc, B vitamins, Omega-3 fatty acids, and protein) early in life can affect the cognitive development of school aged children [54]. Studies also suggest that diets high in trans and saturated fats can negatively impact the brain, influencing learning and memory [38]. Research has also established a link between nutrition and behavior. Studies have found that access to nutrition, particularly breakfast, can enhance a student's psychosocial well-being, reduce aggression and school suspensions, and decrease discipline problems [55]

The impact of good feeding pattern towards students' personality might include;

Better attendance - Several studies, including one in Minnesota, have shown that student attendance improves in schools that implement universal-free school breakfast programs $[56,57,58]$.

Improved behavior - Inner-city students participating in a universal-free school breakfast program had fewer behavior problems six months after the program started [59]. Disciplinary actions also have been shown to decrease in schools that offer a universal-free school breakfast program $[58,60]$. Children whose parents report they often do not get enough to eat are more likely to have been suspended from school, have seen a psychologist, and have difficulty getting along with other children [61].

Improved concentration - A Minnesota study found that a school breakfast program improved concentration and alertness among children [58]. Similarly, children in schools with universal breakfast programs reported having more energy and better attention than those attending schools without universal breakfast programs [62]. An experimental study with 9 through 11-year-old children showed that those who were not served breakfast had slower memory recall [63].

Better academic performance - Many studies indicate that school breakfast programs improve academic performance. Children who do not get sufficient meals are more likely to repeat a grade $[61,64]$.

Elementary children who participated in a school breakfast program in Massachusetts did better on standardized tests than those who qualified but did not participate [57]. Similarly, students in a universal-free school breakfast program at an innercity school showed improved math grade six months after the start of the program [59].

\subsection{Statement of the Problem}

Poor feeding pattern continues to be a problem of public health importance in Nigeria despite the various intervention in the past two decades [19]. Scientific study has reported that high morbidity and mortality in children is attributed to large proportion of Nigerian families who are poorly fed [19]. Hence, high prevalence of protein-energy malnutrition (PEM) and micro nutrient deficiencies [20]. Diet in populations are frequently efficient in macro-nutrient (protein, carbohydrate and fat leading to protein malnutrition), micro nutrient deficiencies) or both and these have diverse effects on the health, academic achievement and the general growth of children $[21,22]$.

Progress to improve the quality of food intake of children in developing countries like Nigeria has been remarkably slow [21] due to several factors such as rise in food cost [22], spending on other necessities [23] and poverty [24]. The relationship between academic achievement and children nutrition are widely recognized [25, 26, 27]. Poor feeding practice are therefore a major threat to the social and economic development as they are among the most serious obstacles to attaining and maintaining normal academic achievement among secondary school students [28]. The effect of Poor feeding pattern has being the subject of much research in the context of developing countries on child well-being. However, very little research has attempted to analyze the effects of Poor feeding pattern of child well-being in Nigeria. [15]

According to [15]. Poor feeding pattern causes iron deficiency in students, which can harm the development of basic motor and social skills. "Hunger can affect learning long before a student goes to school. 'Many of the children whose learning capacity is being affected by food insecurity have been invisible, this is because they are young". "'at the same time the brain is most vulnerable, the brain is most likely to be deprived of nutrition it needs". Thus, the above mentioned problems are sacrosanct, this study aimed at examining poor feeding pattern as a factor militating against students' academic achievement in chemistry which is a mechanism to sustainable development.

\subsection{Research Questions}

The study is out to find answers to the following research questions:

(a) What are the effects of poor feeding pattern on academic achievement of senior secondary school chemistry students?

(b) What are the effects of good feeding pattern on academic achievement of senior secondary school chemistry students?

(c) What is the impact of food on academic achievement 
of senior secondary school chemistry students

(d) Is feeding pattern having influence on Male and Female Senior secondary school chemistry students and their academic achievement in chemistry?

\subsection{Research Hypotheses}

The study sets out hypotheses which are stated in the null form. The formulated hypotheses for the research include the following:

$\mathrm{HO}_{1}$ : Poor feeding pattern has no significant effect on academic achievement of senior secondary chemistry students.

$\mathrm{HO}_{2}$ : good feeding pattern has no significant effect on academic achievement of senior secondary chemistry students.

$\mathrm{HO}_{3}$ : Food has no significant role in enhancing academic achievement of senior secondary chemistry students.

$\mathrm{HO}_{4}$ : Effects of feeding pattern on academic achievement of chemistry students is not gender sensitive.

\section{Methodology}

The research design adopted for this study is survey, focusing on feeding pattern as a factor militating against students' achievement in chemistry; a mechanism for sustainable development. [29] Also said that large and small population can be studied using this method, hence the use of this method shall be adopted by the researcher. The population of this research work constitutes some selected secondary schools in Sabon Gari Local Government Area of Kaduna state. The selected schools are a total of six (6) senior secondary school with a total population of one thousand, five hundred and eleven $(1,551)$ students.

A total of 306 respondents from all the six (6) selected senior secondary schools in Sabon Gari Local Government Area shall be in this study. Sample size was chosen in line with [30] sample size table. This is to make sure all students are duly represented in the study. Simple random sampling was used to select the targeted number of respondents from all schools to represents the sample for study. The main instrument for data collection in this study is a researcher designed questionnaire titled Feeding Pattern as a Factor Militating against Students' Achievement in Chemistry Questionnaire (FPMSACQ) and also their examination results for first term 2014/2015 academic session was used in the study. The researcher visited all the sampled schools and administer the questionnaire to the respondents/students.

Data analysis is the process of systematically applying statistical and/or logical techniques to describe and illustrate, condense and recap, and evaluate data. Therefore, in this research work, the researcher used the statistical package for Social Science (SPSS, version 20) as a statistical tool for data analysis.

\section{Results and Discussion}

Table 1. The Academic Performance of the Students in Chemistry.

\begin{tabular}{llllll}
\hline S/N & $\begin{array}{l}\text { Name of } \\
\text { Schools }\end{array}$ & Sample & $\begin{array}{l}\text { Percentage } \\
(\%)\end{array}$ & $\begin{array}{l}\text { No. } \\
\text { Pass }\end{array}$ & $\begin{array}{l}\text { No. } \\
\text { Fail }\end{array}$ \\
\hline 1 & GSSA & 46 & 15 & 26 & 20 \\
2 & GSSM & 60 & 20 & 48 & 12 \\
3 & GGSSD/B & 95 & 31 & 65 & 30 \\
4 & DLS & 50 & 16 & 31 & 19 \\
5 & MIS & 20 & 7 & 16 & 4 \\
6 & GHIS & 35 & 11 & 21 & 14 \\
& Total & 306 & 100 & 207 & 99 \\
\hline
\end{tabular}

KEY:

GSSA - Government Secondary School, Aminu

GSSM - Government Secondary School, Muchia

GGSSD/B - Government Girls Secondary School, Dogon Bauchi

DLS - Dagamas Legacy School

MIS - Maude International School

GHIS - Great Hall Mark International School

The table 1 above shows that out of the 306 sample size, 207 passed chemistry while 99 of the respondents fail chemistry examination. The table shows that 26 students from the sample of GSSA passed Chemistry while 20 failed from the 46 sampled students, also, 48 students from GSSM passed Chemistry while 12 students failed chemistry from the 60 sampled students. Moreover, it is evident that 65 students from GSSD/B passed Chemistry while 30 students failed Chemistry from the 95 sampled students. Also, 31 students from DLS passed Chemistry while 19 failed Chemistry from the 50 sampled students. From MIS, out of 20 sampled students 16 passed Chemistry and failed Chemistry. So also, from GHIS, out of the 35 sampled students, 21 passed Chemistry while 14 failed Chemistry. Thus, the information provided shows that the students from all the selected schools perform well in Chemistry.

In order to answer the first research question which sought to establish if feeding pattern affects academic achievement of senior secondary school students in the study area and the null hypothesis which says; feeding pattern has no significant effect on academic achievement of senior secondary chemistry students in Sabon Gari L. G. A of Kaduna state. The collected data was subjected to T- test using Statistical Package for social science version 20 (SPSS), the result were presented in the table below.

Table 2. T- Test Analysis of Achievement and Poor Feeding Pattern among Senior Secondary Chemistry Students in Sabon Gari LGA.

\begin{tabular}{|c|c|c|c|c|c|c|c|c|}
\hline Variable & $\mathbf{N}$ & $\mathbf{X}$ & S. D & S. E & Df & t- value & $\mathbf{P}$ & Remarks \\
\hline Achievement & 306 & 47.42 & 18.85 & 1.08 & 305 & 0.21 & 0.835 & Insign. \\
\hline Poor Feeding Pattern & 306 & 13.654 & 3.125 & 0.179 & 305 & & & \\
\hline
\end{tabular}

Significant@P $\leq 0.05$

Thus, from the data obtained from the respondents, it is clear evident that the students are classified as individuals with good feeding pattern since the mean of their poor feeding habit was found to be 13.65. Good nutrition is important to supporting growth and maximizing learning potential. Due to current research, people are becoming 
increasingly educated on the role nutrition plays on the body's and mind's ability to grow and the performance of our potential learning capacity. Nutritional intake affects energy levels, physical stamina, mood, memory, mental clarity, and emotional and mental well-being. Research is proving good nutrition is pertinent for the brain, so the old adage, "You are what you eat" is proving to be true. Parents and educators need to educate today's youth to make healthier food choices because they are being raised in a culture of fast food [31]. Adequate and sufficient healthy intake of food is essential to brain function [32, 33, 34, 35]. Moreover, maximizing brain function is a prime factor in seizing appropriate cognitive capability - for example, ability to focus, comprehension, evaluation, and application - in learning $[36,37]$. Thus the data obtained shows that there is no significant link between good academic performance and poor feeding pattern even though according to $[38,39]$ who stated that; Yet, while there may be a consensus that food is essential to learning, there is little empirical research that examines the exact relationship between children's overall diet and academic achievement. Neither are the results conclusive in determining the precise nature and degree of the food-learning relationship.

Table 3. T- Test Analysis of Achievement and Good Feeding pattern among Senior Secondary Chemistry Students in Sabon Gari LGA.

\begin{tabular}{|c|c|c|c|c|c|c|c|c|}
\hline Variable & $\mathbf{N}$ & $\mathbf{X}$ & S. D & S. E & Df & t- value & $\mathbf{P}$ & Remarks \\
\hline Achievement & 306 & 47.42 & 18.85 & 1.08 & 305 & 4.31 & 0.02 & Sign. \\
\hline Good Feeding Pattern & 306 & 43.13 & 7.34 & 0.81 & 305 & & & \\
\hline
\end{tabular}

Significant @ $\mathrm{P} \leq 0.05$

Even though the results shows that good feeding pattern has significant effect on students' performance since $\mathrm{P} \leq 0.05$, it is good to take care of students meal since they spent most of their time at school. According to [40] who stated that due to the considerable amount of time children spend at school more attention needs to be paid to the food options that are available if we want healthy eating to become a normal lifelong behavior. Schools can't ignore the importance of supporting healthy habits since about $35 \%$ of a student's daily calories are consumed at school. More research needs to be done to gather more information to show a correlation between nutrition and cognitive function and academic performance. Good nutrition is important to supporting growth and maximizing learning potential. Due to current research, we are becoming increasingly educated on the role nutrition plays on the body's and mind's ability to grow and the performance of our potential learning capacity. Nutritional intake affects energy levels, physical stamina, mood, memory, mental clarity, and emotional and mental well-being. Research is proving good nutrition is pertinent for the brain, so the old adage, "You are what you eat" is proving to be true. Parents and educators need to educate today's youth to make healthier food choices because they are being raised in a culture of fast food [32]. Thus the table above provides answer to research question two and a solution to the null hypothesis two.

Table 4. Responses of Senior Secondary School Students to Academic Achievement in Relation to Food.

\begin{tabular}{|c|c|c|c|c|c|}
\hline S/No & Role of Food & Yes & $\%$ & No & $\%$ \\
\hline 1. & Do you live with your parents? & 259 & 84.64 & 47 & 15.46 \\
\hline 2. & Is there enough food in your home? & 290 & 94.77 & 16 & 5.23 \\
\hline 3. & Do you eat before going to school in the morning? & 283 & 92.48 & 23 & 7.52 \\
\hline 4. & Do you always have enough of the kinds of food you want to eat? & 233 & 76.14 & 73 & 23.96 \\
\hline 5. & Do you have enough to eat, but not always the kind of food you wanted? & 184 & 60.13 & 122 & 39.87 \\
\hline 6. & $\begin{array}{l}\text { In the past six months, did you ever cut the size of your meals or skip meals because there wasn't } \\
\text { enough money for food? }\end{array}$ & 236 & 77.12 & 70 & 22.88 \\
\hline 7. & Were you ever hungry but didn't eat because you couldn't afford food? & 205 & 66.99 & 101 & 33.10 \\
\hline 8. & Do you meet food at home immediately you go back home from school? & 230 & 75.16 & 76 & 24.84 \\
\hline 9. & Do you eat balanced or nutritious meal often? & 190 & 62.09 & 116 & 37.91 \\
\hline 10. & Do you eat from your friends because you are hungry? & 128 & 41.83 & 178 & 58.17 \\
\hline 11. & In the past six months, did you lose weight because you didn't have enough money for food? & 160 & 52.29 & 146 & 47.71 \\
\hline 12. & Do you eat carbohydrate food such as maize, potatoes, rice, and yam daily? & 263 & 85.95 & 43 & 14.05 \\
\hline 13. & Do you eat protein rich food (E.g Egg, Beans, Milk, e.t.c) daily? & 145 & 47.39 & 161 & 52.61 \\
\hline 14. & Do you receive financial aid from government? & 50 & 16.34 & 256 & 83.66 \\
\hline 15. & Do you receive financial aid from any family relative? & 91 & 29.74 & 215 & 70.36 \\
\hline 16. & Do you work after school hours in order to get money for food? & 101 & 33.00 & 205 & 67.00 \\
\hline 17. & Do you think poverty is the cause of food insecurity? & 203 & 66.34 & 103 & 33.66 \\
\hline 18. & Is food insecurity caused by over population in your family? & 97 & 31.70 & 209 & 68.30 \\
\hline 19. & Have you ever missed school because you are hungry? & 70 & 22.88 & 236 & 77.18 \\
\hline 20. & Have you ever fainted because of hunger? & 24 & 7.84 & 282 & 92.16 \\
\hline 21. & Do you understand what your teacher teaches you when you are hungry? & 32 & 10.46 & 274 & 89.54 \\
\hline 22. & Does hunger makes you fight your fellow students in school? & 142 & 46.41 & 164 & 53.69 \\
\hline 23. & Can you read with hunger in your stomach? & 63 & 20.59 & 243 & 79.41 \\
\hline 24. & Do you understand what you read/ study when hungry? & 38 & 12.42 & 268 & 87.68 \\
\hline 25 . & Do any of your family member drops out of school because of poverty? & 48 & 15.69 & 258 & 84.31 \\
\hline 26 & Students that are properly fed perform better in class activities? & 198 & 64.71 & 108 & 35.29 \\
\hline 27 & When students are hungry do they tends to misbehave in class? & 215 & 70.26 & 91 & 29.74 \\
\hline
\end{tabular}


In a quest to find answer to research question three and hypothesis three the result in table 4 indicates the responses of the students on the role of food insecurity in relation to academic achievements. The result revealed that 259 respondents which accounts for $84.64 \%$ agreed on having food to eat while 47 representing $15.46 \%$ disagreed. This simply means that more than half of the respondents have food to eat. Furthermore, the table also showed that 290 which account for $94.77 \%$ of the respondents take breakfast before going to school on daily basis. While 16 which account for 5.23\% don't take breakfast before proceeding to school. Also the table shows that 233 respondents corresponding to $76.14 \%$ opined that they have enough of the kinds of food they want to eat at home while 73 which account for $7.52 \%$ said that they don't have enough of what they want to eat at home. Moreover, 236 students which account for $77.12 \%$ have in one way or the other cut the size of meals they eat because there is no enough money for food within the past six months. 205 respondents accounting for $66.99 \%$ agree that they are once hungry but didn't eat because they can't afford food while 101 respondents accounting for $33.10 \%$ oppose the motion. 230 students said that they do eat food immediately when they go back home from school are they accounted for $75.16 \%$ of the respondents while 76 respondents accounting for $24.84 \%$ said they do not eat food immediately when they arrive home from school. Also, 190 respondents accounting for $62.09 \%$ often eat balanced nutritious meal while 116 corresponding to $37.9 \%$ opined that they do not often eat nutritious meals. 128 respondents accounting for $41.83 \%$ said that they do eat from friends when they are hungry while 178 accounting for $58.17 \%$ said they don't eat from friends even when they are hungry. 160 respondents equivalent to $52.29 \%$ says that in the past six months they've lost weight owe to unavailability of money for food while 146 equivalents to $47.69 \%$ opined that they do not lose weight owe to lack of food in the past six months. Moreover, 263 respondents accounting for $85.95 \%$ says that they do eat carbohydrates daily while 43 accounting for $14.05 \%$ say that they don't often eat carbohydrates. Statistics from table 1 also showed that $15.69 \%$ of the respondents when hungry understands everything they are been taught by their teachers while $84.31 \%$ of the respondents disagreed to this claim. According to [15], hunger can lead to deficiency of iron in students which can harm the development of basic motor and social skills. Descriptive statistics in table 1 also showed that $22.8 \%$ of the respondents have missed school at one time or the other as a result of hunger, $77.18 \%$ of the respondents claimed not to have missed school at any point as a result of hunger. This shows that food plays an important role in the academic achievement of student which agrees with [32] who stated that Good nutrition is important to supporting growth and maximizing learning potential. Due to current research, we are becoming increasingly educated on the role nutrition plays on the body's and mind's ability to grow and the performance of our potential learning capacity. Nutritional intake affects energy levels, physical stamina, mood, memory, mental clarity, and emotional and mental well-being. Research is proving good nutrition is pertinent for the brain, so the old adage, "You are what you eat" is proving to be true. Parents and educators need to educate today's youth to make healthier food choices because they are being raised in a culture of fast food. And also supports the works of [41] who reported that, poor feeding at kindergarten predicted impaired academic performance in mathematics for girls and boys, and greater weight and BMI gains for girls. Food insecurity thus, serves as an important marker for identifying children with delayed trajectories of development.

\section{\& sensitive $\mathbb{N}$ insensitive}

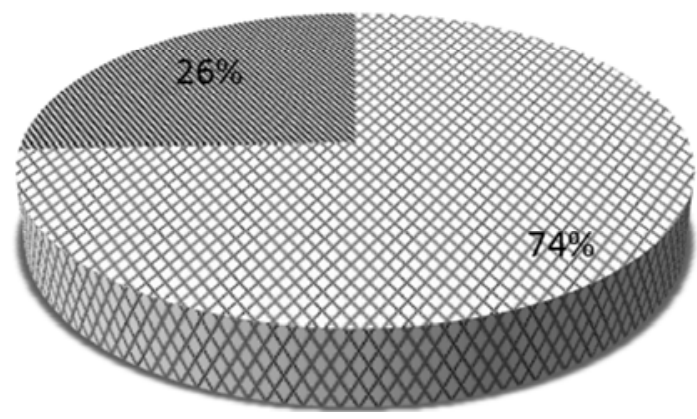

Figure 1. Relationship between Gender and Food Insecurity.

Considering effects of food insecurity and gender, $70.6 \%$ of the respondents believe that food insecurity is gender sensitive while $29.4 \%$ of the respondents disagree with the aforementioned. Also $70.60 \%$ of the respondents believe that food insecurity tend to affects females than males. [42] Reports that food insecurity negatively impacts on school attendance and educational attainment of adolescents in the south west Ethiopia. His findings suggest that food security interventions should consider ways of enhancing school attendance and look into mechanisms for improving the diet of school children directly through school based programs. According to [43] poor feeding can have a serious negative impact on students' success- academic, behavioral and social. [44] Opined that children from households that report insufficiency of food generally do not perform as well on tests of academic achievement as children from food sufficient households. According to [15], hunger can lead to deficiency of iron in students which can harm the development of basic motor and social skills.

\section{Conclusion}

The research increasingly supports the important link between nutrition and learning potential. Healthy eating is essential for students to achieve their full academic potential, mental growth, and lifelong health and well-being. When 
children are not receiving proper nutrition they are unable to reach their full potential. Schools need to educate parents and children on how to live a healthy lifestyle that includes proper nutrition. Improvements in the nutritional quality of students' diets are associated with academically beneficial gains, but have not been repeatedly and causally correlated to increased academic achievement. Concrete links between food consumption either at large or in specific foods and academic performance have not been established, likely because of the complex nature of the variables, the abundant confounders, and the longitudinal design necessary to understand the enduring effects. In general, however, it is clear that consistently eating sufficient quantity and variety of nutrient-dense foods will improve children's diet quality, and consequentially reduce the potential for the cognitive impairments associated with malnutrition.

This study has shown that food availability or good feeding pattern has a vital role to play when it comes' to academic achievement of students. The outcome of this study was found to conform to literatures from several studies of academic performance which were cited and reviewed in this study.

\section{Recommendations}

Based on the findings of this study the following recommendations are put forward by the researchers:

(1) Government should consider funding education for orphans and those students who belong to impoverished families in order to reduce school drop outs having discovered that a large proportion of students have had to drop out because of hunger to engage in menial jobs.

(2) Parents' low level education may be the cause of their unemployment and low incomes, it is recommended that Government and donor organizations should embark on poverty alleviation programmes that will make poverty stricken parent earn a living.

(3) Inculcation of school nutritional program aimed at improving malnutrition in schools having discovered that food insecurity plays a vital role in academic achievement. Even though it shows no significance on students within the study area.

(4) Non-Governmental Organizations, WHO, UNICEF and UNESCO should lay more emphasis on eradicating food insecurity and malnutrition among children.

\section{References}

[1] Lutter, C. K, Rivera JA (2003). Nutritional Status of Infants and Young children and characteristics of Their Diets. J. Nutr. 133: 2941s- 2949s.I Martorell R, editors. Anthropometric Standardization Reference Manual. Champaign, IL: Human Kinetics Books. 3-8.

[2] USDA. (2003). Food Insecurity. United States Department of Agriculture Economic Research Service. Retrieved from http://www.ers.usda.gov/topics/food-nutritionassistance/foodsecurity-in-the-us.aspx\#.Up6hqNJDuSo.
[3] Ecker, O. \& Nene, M. 2012. Nutrition policies in developing countries: Challenges and highlights. Policy Note 1. Washington DC, International Food Policy Research Institute. Encarta (2009). Private/Public School. USA: Microsoft Incorporation.

[4] Nabarro, D., Menon, P., Ruel, M. \&Yosef, S. (2012). S caling Up Nutrition: A global movement to accelerate progress in reducing maternal and child under-nutrition. Brief 9. In: J. Linn. (ed.).

[5] Shrestha, I. \& Pathak, L. (2012). A Review of the National Health Policy 1991. Katmandu: Ministry of Health and Population.

[6] Lacour, M. \&Tissington, LD. 2011. Educational research and reviews. Academic Journal, 7 (9): 522-527.

[7] Akinade, E. A. (2001). Modern concise dictionary of psychology. Lagos: Pumack Nigerian Limited.

[8] Hassan, T. (2006). Educational assessment in Nigeria; a paradox of a victim of its own failure. Retrieved from www.google.com on 13/04/2007.

[9] Salami, S. D (2001). Psychological correlates of career indecision among secondary school adolescents. Nigerian Journal of Applied Psychology, 6 (2) 116-125.

[10] Aremu, S. (2001). Academic performance five-factor inventory. Ibadan; Stirling-Holden Publishers.

[11] Encarta (2009). Private/Public School. USA: Microsoft Incorporation.

[12] Bruntland Commision, (1987). Our common future. Oxford University Press: oxford.

[13] Crawley, P. (2004). Economic Security and Regional Integration in Southeast Asia. Address to the National Economic Outlook 2005 Conference held by the Malaysian Institute of Economic Research (MIER) in Kuala Lumpur, December 7, 2004. Asian Development Bank Institute.

[14] UNESCO (2011). EFA Global Monitoring Report: The Hidden Crisis: Armed conflict. Paris: UNESCO.

[15] Seligman, H, (2012). Food insecurity and glycemic control among low-income patients with type 2 diabetes. Diabetes Care 35 (2): 233-38.

[16] Derek DH (2013). The Impact of the Global food crisis on selfassessed food security. World Bank Econ Rev, 27 (1), 1-27.

[17] Lyles, C, (2013). Food insecurity in relation to changes in hemoglobin A $1 \mathrm{c}$, self-efficacy, and fruit/vegetable Intake during a diabetes educational intervention. Diabetes Care 36 (6): 1448-53.

[18] Rahul, R, (2013). Poordiet quality is associated with low CD 4 count and anemia and predicts mortality among antiretroviral therapy-naive HIV-positive adults in Uganda. JAIDS, 62 (2): 246-53.

[19] Sanusi, RA, Badejo CA, Yusuf BO (2006). Measuring household food insecurity in selected local government areas of Lagos and Ibadan, Nigeria. Pakistan Journal of Nutrition, 5 (1): 62-67.

[20] Ijarotimi, O. S, Oyeneyin, O. O. (2005). Effect of economic restructuring on household food security and nutritional status of Nigerian children. J. Food Agric. Environ. 3 (3\&4): 27-32. 
[21] Maziya-Dixon B, Akinyele IO, Oguntona EB, Nokoe S, Sanusi RA, Harris E (2013). Nigeria Food Consumption and Nutrition Survey 2001-2003. International Institute of Tropical Agriculture (IITA).

[22] Crawley, P. (2004). Economic Security and Regional Integration in Southeast Asia. Address to the National Economic Outlook 2005 Conference held by the Malaysian Institute of Economic Research (MIER) in Kuala Lumpur, December 7, 2004. Asian Development Bank Institute.

[23] Keikhaei B, Zandian K, Ghasemi A, Tabibi R (2007). Irondeficiency anemia among children in southwest Iran. Food Nutr. Bull., 28 (4): 406-411.

[24] Meyers A, Frank D, Roos N, Peterson KE, Casey VA, Cupples LA, Levenson SM (2008). Housing subsidies and pediatric under-nutrition. Arch. Ped. Adoles. Med. 149: 1079-1084.

[25] Udani PM (2002). Protein energy malnutrition (PEM), brain and various facets of child development Indian J. Pediatr. 59, 165-186.

[26] United Nations Food Conference. (2004). The World Food Problem: Proposals for National and International Action (Mimeo) Rome.

[27] Dauncey, M. J. (2009). New insights into nutrition and cognitive neuroscience. Proceedings of the Nutrition Society (68), 408-415. Educational Supplement, pp. N\&O 8.

[28] WHO (2002). Childhood nutrition and progress in implementing the International Code of Marketing of Breastmilk Substitutes. Geneva, World Health Organization, 2002 (document A 55/14).

[29] Udani PM (2002). Protein energy malnutrition (PEM), brain and various facets of child development Indian J. Pediatr. 59, 165-186.

[30] Jibril, M. (2000). Annual Report: Security unit. Abuja: National Universities commission.

[31] Krejcie, Robert., Morgan, Daryle, W. "Determining Sampling Size for Research Activities", Educational and Psychological Measurement, 1970.

[32] Mayer, N. \& Jencks, S. (2008). Food security in Southern Africa: review of lessons learnt on responses to chronic and transitory hunger and vulnerability. Natural Resource Perspective no. 106. London: Overseas Development Institute.

[33] Bloom, A. (2009, May 22). Revealed: Fast food diet can result in slow-brain children. Times Educational Supplement, pp. $\mathrm{N} \& \mathrm{O} 8$.

[34] Dauncey, M. J. (2009). New insights into nutrition and cognitive neuroscience. Proceedings of the Nutrition Society (68), 408-415. Educational Supplement, pp. N\&O 8.

[35] Kazal, L. A. (2002). Prevention of iron deficiency in infants and toddlers. American Family Physician (66) 7, 1217-1224. Retrieved from http://www.aafp.org/afp

[36] Shariff, Z. M., Bond, J. T., Johnson, N. E. (2000). Nutrition and educational achievement of urban primary schoolchildren in Malaysia. Asia Pacific Journal of Clinical Nutrition (9) 4, 264-273. Retrieved from EBSCOHost.

[37] Kretchmer, N., Beard, J. L., Carlson, S. (1996). The role of nutrition in the development of normal cognition. The American Journal of Clinical Nutrition (63), 997 S-1001 S.
Retrieved from http://www.ajcn.org.

[38] Schmitt, J. A. J. (2010). Nutrition and cognition: Meeting the challenge to obtain credible and evidence-based facts. Nutrition Reviews, 68 (suppl. 1), S 52-55.

[39] Gomez-Pinilla, F. (2008). Brain foods: The effects of nutrients on brain function. National Review of Neuroscience, 9 (7), 568-578. doi: 10.1038/nrn 2421.

[40] Hollar, D., Messiah, S. E., Lopez-Mitnik, G., Hollar, L., Almon, M., \& Agatston, A. S. (2010). Effect of a two-year obesity prevention intervention on percentile changes in body mass index and academic performance in low-income elementary school children. American Journal of Public Health, 100, 646-653.

[41] Neumark-Sztainer, D., French, S., Hannan, P., Story, M., \& Fulkerson, J. (2005). School lunch and snacking patterns among high school students: associations with school food.

[42] Nutr, J. (2005). food insecurity affects school childrens academic operformance, weight gain, and social skills. Dec; 135 (12): 2831-9.

[43] Belachew, et, al. (2011). Food insecurity, school absenteeism and educational attainment of adolescents in Jimma Zone Southwest Ethiopia. A longitudinal study.

[44] Clare, L. Cady. (2014). Food Insecurity as a students Issue, Taylor and Francis Online Publications.

[45] Brown, J. Larry. 2009. "When Violence Has a Benevolent Face: The Paradox of Hunger in the World's Wealthiest Democracy." International Journal of Health Services, 19:257-277.

[46] Centers for Disease Control. (2013). Childhood obesity facts. Retrieved from http://www.cdc.gov/healthyyouth/obesity/facts.htm

[47] Minnesota Department of Health. (2012 a). Children \& adolescent overweight fact sheet. Retrieved from: http://www.health.state.mn.us/cdrr/obesity/pdfdocs/childrenov erwightfactsheet.pdf

[48] Coleman-Jensen, A., Nord, M., \& Singh, A. (2013). Household food security in the United States in 2012. Retrieved from United States Department of Agriculture Economic Research Service website: http://www.ers.usda.gov/publications/err-economic-researchreport/err155.aspx\#.Um7t7BDHigl

[49] Second Harvest Heartland. (2013). Hunger facts. Retrieved from: http://www.2harvest.org/pdf/hunger_facts_2013.pdf

[50] Florence, M. D., Asbridge, M., \& Veugelers, P. J. (2008). Diet quality and academic performance. Journal of School Health, 78 (4), 209-215.

[51] Li, J., \& O'Connell, A. A. (2012). Obesity, high-calorie food intake, and academic achievement trends among U.S. school children. The Journal of Educational Research, 105 (6), 391-403.

[52] Belot, M., \& James, J. (2009). Healthy school meals and educational outcomes. Journal of Health Economics, 30 (3), 489-504.

[53] Brown, J. L., Beardslee, W. H., \& Prothrow-Stith, D. (2008). Impact of school breakfast on children's health and learning: An analysis of the scientific research. Retrieved from the Sodexo Foundation website 
[54] http://www.sodexofoundation.org/hunger_us/Images/Impact $\%$ 20of\%20School\%20Breakfast\%20Study_tcm 150-212606.pdf

[55] Bellisle, F. (2004). Effects of diet on behaviour and cognition in children. British Journal of Nutrition, 92 (2), S 227-S 232. Retrieved from

http://hundsundskolerestaurant.no/wordpress/wpcontent/uploa ds/2010/11/Bellisle-sugar-and-cognition-in-children-2004.pdf

[56] Sorhaindo, A., \& Feinstein, L. (2006). What is the relationship between child nutrition and school outcomes? Retrieved from the Centre for Research on the Wider Benefits of Learning website:

http://www.learningbenefits.net/Publications/ResReps/ResRep 18.pdf

[57] Brown, J. L., Beardslee, W. H., \& Prothrow-Stith, D. (2008). Impact of school breakfast on children's health and learning: An analysis of the scientific research. Retrieved from the Sodexo Foundation website:

http://www.sodexofoundation.org/hunger_us/Images/Impact\% 20of\%20School\%20Breakfast\%20Study_tcm 150-212606.pdf

[58] Cook, J. T., Ohri-Vachaspati, P., \& Kelly, G. L. (1996). Evaluation of a universally-free school breakfast program demonstration project, Central Falls, Rhode Island. Medford, MA: Center on Hunger, Poverty and Nutrition Policy, Tufts University.

[59] Meyers, A. F., Sampson, A. E., Weitzman, M., Rogers, B. L., \& Kayne, H. (1989). School breakfast program and school performance. American Journal of Diseases of Children, 143 (10), 1234-9.

[60] Wahlstrom, K. L., \& Begalle, M. S. (1999). More than test scores: Results of the universal school breakfast pilot in MN. Topics in Clinical Nutrition, 15 (1), 17-29.
[61] Kleinman, R. E., Hall, S., Green, H., Korzec-Ramirez, D., Patton, K., Pagano, M. E., \& Murphy, J. M. (2002). Diet, breakfast and academic performance in children. Annals of Nutritional Metabolism, 46 (Suppl 1), 24-30.

[62] Murphy, J. M., Drake, J. E., \& Weineke, K. M. (2005). Academics \& Breakfast Connection Pilot: Final report on New York's classroom breakfast project. Retrieved from Nutrition Consortium of New York State website: http://www.gotbreakfast.org/news/NYS_bkfastinclass_studyre sults_ABCfinal.pdf

[63] Alaimo, K., Olson, C. M., \& Frongillo, E. A., Jr. (2001). Food insufficiency and American children's cognitive, academic and psychosocial development. Pediatrics, 108 (3), 824b.

[64] Redden, J., Wahlstrom, K., \& Reicks, M. (2002). Children's perceived benefits and barriers in relation to eating breakfast in schools with or without universal school breakfast. Journal of Nutrition Education \& Behavior, 34 (1), 47-52.

[65] Pollitt, E., \& Matthews, R. (1998). Breakfast and cognition: An integrative summary. American Journal of Clinical Nutrition, 67 (4), 804 S-813 S. Retrieved from: http://ajen.nutrition.org/content/67/4/804S.full.pdf

[66] Kleinman, R. E., Murphy, J. M., Little, M., Pagano, M., Wehler, C. A., Regal, K., \& Jellinek, M. S. (1998). Hunger in children in the United States: Potential behavioral and emotional correlates. Pediatrics, 101 (1), E 3. Retrieved from: http://pediatrics.aappublications.org/content/101/1/e 3.long

[67] Nutrition and Students' Academic Performance, (2014) 451 Lexington Parkway North | Saint Paul, Minnesota 55104 651280-2700 | www.wilderresearch.org 